\title{
Phantom tumour of the lung
}

\author{
Bárbara Lobão, Eugenio Dias
}

Department of Internal Medicine, Centro Hospitalar de Setubal, Setubal, Portugal

\section{Correspondence to}

Dr Bárbara Lobão, babilobao@hotmail.com
To cite: Lobão B, Dias E. BMJ Case Rep Published online: [please include Day Month Year] doi:10.1136/ bcr-2013-008660

\section{DESCRIPTION}

A 55-year-old man with no clinically relevant medical history presented with a 7-day history of right-sided pleuritic chest pain, non-productive cough and night sweats. Physical examination showed no clinical signs of respiratory distress. The laboratory results revealed an elevated C-reactive protein of $5.02 \mathrm{mg} / \mathrm{dl}$ and an increased erythrocyte sedimentation rate of $110 \mathrm{~mm} / \mathrm{h}$. A posteroanterior chest radiograph showed a phantom tumour as a well-delineated, drop-shaped density in the right middle lung field (figure 1). A CT scan identified multiple mediastinal and right hilar lymphadenopathy, and confirmed a homogenous loculated effusion in the right major fissure, a so-called 'pulmonary pseudotumour'. A tuberculin skin test was strongly positive. A diagnostic thoracentesis showed a lymphocyte-rich exudative pleural effusion with a high level of adenosine deaminase.

Tuberculous pleural effusion was diagnosed and a 6-month anti-tuberculosis standard regimen was started.

Follow-up examination at the end of treatment revealed resolution of symptoms and radiograph showed complete resolution of the opacity.

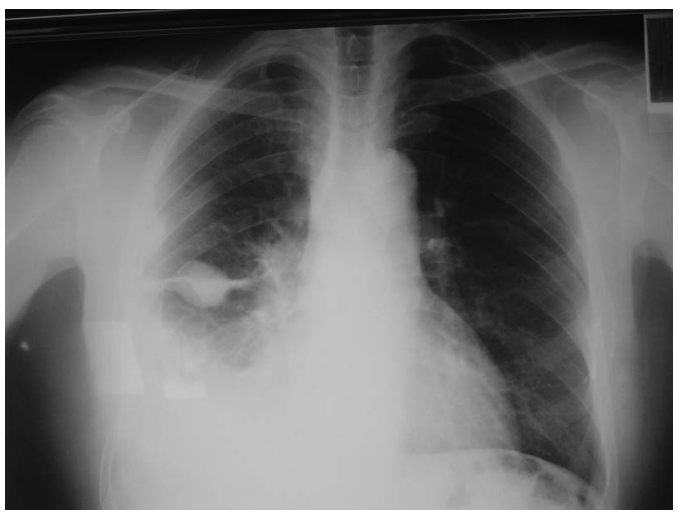

Figure 1 Chest $x$-ray showing a phantom tumour of the lung with a well-delineated, drop-shaped density in the right middle lung field.

\section{DISCUSSION}

Pseudotumours of the lung are transient collections of pleural fluid in the interlobar pulmonary fissure predominantly on the right side, which can be seen in lung infections, congestive heart failure, renal failure and hypoalbuminemia. The pathogenesis involves the adhesion and obliteration of the pleural space due to pleuritis that may be transient, thereby preventing the free accumulation of fluid. ${ }^{12}$

Recognition of this radiographic presentation is important because it may be a rare sole manifestation of tuberculosis and because unnecessary diagnostic procedures and therapeutic errors may be prevented as the main differential diagnosis is pulmonary nodule and/or mass.

\section{Learning points}

- The diagnosis of a phantom tumour is facilitated when there is evidence of fluid in the large pleural cavity.

- Recognition of this radiographic presentation is important because it may be a rare sole manifestation of tuberculosis; it also avoids unnecessary investigation for a pulmonary malignancy.

- Managing the underlying condition leads to resolution of the pseudotumour.

\section{Competing interests None.}

Patient consent Obtained.

Provenance and peer review Not commissioned; externally pee reviewed.

\section{REFERENCES}

1 Athappan G, Ariyamuthu VK, Rajamani V. Phantom tumor of the lung. Internet J Cardiol 2007;5. doi: 10.5580/2411

2 Lopes AJ, Jansen U, Capone $D$, et al. Diagnóstico de falsos tumores do pulmão. Pulmão (RJ) 2005;14:33-42.

Copyright 2013 BMJ Publishing Group. All rights reserved. For permission to reuse any of this content visit http://group.bmj.com/group/rights-licensing/permissions.

BMJ Case Report Fellows may re-use this article for personal use and teaching without any further permission.

Become a Fellow of BMJ Case Reports today and you can:

- Submit as many cases as you like

- Enjoy fast sympathetic peer review and rapid publication of accepted articles

- Access all the published articles

- Re-use any of the published material for personal use and teaching without further permission

For information on Institutional Fellowships contact consortiasales@bmjgroup.com

Visit casereports.bmj.com for more articles like this and to become a Fellow 